\title{
School Based Intervention on Overweight in Children: A Meta Analysis
}

\author{
Riftiani Nikmatul Nurlaili'), Yulia Lanti Retno Dewi²), Rita Benya Adriyani3) \\ 1)Masters Program in Public Health, Universitas Sebelas Maret \\ 2)Faculty of Medicine, Universitas Sebelas Maret \\ 3)Diploma Program in Speech Therapy, School of Health Politechnics Surakarta
}

\section{ABSTRACT}

Background: Overweight is a serious nutritional problem in children. Currently, overweight is a nutritional problem in all countries, both developed and developing countries. One of the efforts to stop increasing overweight in children is to provide school-based interventions. This study aims to estimate the magnitude of the effect of school-based interventions on overweight in children based on a number of previous primary studies.

Subjects and Method: Meta-analysis was performed by systematically reviewing articles from Google Scholar, PubMed, BMJ, ScienceDirect, BMC, and Sage. The articles used in this research are articles that have been published from 2007-2018. Keywords for searching articles are as follows: (preschool OR school) AND (intervention OR program prevention) AND ("children obesity" OR "children overweight") AND "randomized control trials" and "preschool based" OR "school based" AND intervention OR prevention OR program AND "childhood obesity" OR "childhood overweight" OR "children obesity" OR "children overweight". The inclusion criteria used were full paper, used English, randomized controlled trials study design and the results reported Risk
Ratio (RR). Articles are collected using PRISMA diagrams and analyzed using the Review Manager 5.3 application.

Results: A total of 10 articles were reviewed in this study. Between experimental groups were homogeneous $\left(I^{2}=0 \% ; p=0.570\right)$, therefore this study was conducted using a fixed effect model. Studies show that school-based interventions have the effect of reducing the BMI of overweight children $(\mathrm{RR}=0.89 ; 95 \% \mathrm{CI}=0.82$ to $0.97 ; \mathrm{p}=0.007$ ) in China, the United States, Mexico, Germany, Portugal, France, and the UK.

Conclusion: School-based interventions have the effect of reducing the risk of overweight in children in China, the United States, Mexico, Germany, Portugal, France, and the UK.

Keywords: School-based intervention, overweight children

\section{Correspondence:}

Riftiani Nikmatul Nurlaili. Masters Program in Public Health, Universitas Sebelas Maret, Jl. Ir. Sutami 36A, Surakarta 57126, Central Java. Email: riftiani.nurlaili@gmail.com. Mobile: o85746737137.

Cite this as:

Nurlaili RN, Dewi YLR, Adriyani RB (2020). School Based Intervention on Overweight in Children: A Meta Analysis. J Matern Child Health. 05(06): 683-692. https://doi.org/10.26911/thejmch.2020.05.06.08.

(c) (i) (2) Journal of Maternal and Child Health is licensed under a Creative Commons EY NC SA Attribution-NonCommercial-ShareAlike 4.0 International License.

\section{BACKGROUND}

Overweight is a serious nutritional problem in children. The number of overweight children reached 216 million in 2016 (WHO 2020). The highest prevalence is in the six sub-regions of the United Nations (UN), namely; Australia and New Zealand 20.7\%,
South Africa 12.7\%, North Africa 11.3\%, Oceania 9.4\%, North America 8.9\%, and West Asia 8.4\% (UNICEF, WHO, 2020). Obesity is a problem in all countries, both developed and developing countries (UNICEF, WHO, 2020). 
Nutritional problems become a double burden, where on the one hand they still deal with wasting and stunting, but on the other hand, the problem of overweight is also increasing. It is estimated that 4.5 million children under five are currently overweight in ASEAN member countries (UNICEF, 2016). The prevalence of obesity in children in ASEAN member countries, namely; Indonesia $12 \%$, Thailand $11 \%$, Brunei 8\%, Malaysia 7\%, Philippines 5\%, Vietnam 4\%, Myanmar 3\%, Cambodia 2\%, and Lao PDR 2\% (UNICEF, 2016).

Overweight is excess body fat mass (Schwartz et al., 2017). Overweight children have a 5 times greater risk of becoming obese in adulthood (Simmonds et al, 2016). So it is necessary to make efforts to reduce the nutritional status of overweight in children to normal nutrition.

In 2012, WHO member countries agreed to endeavor to stop increasing overweight in children by 2025 so that it became one of the six global nutrition targets in the Comprehensive Implementation Plan for Maternal, Infant, and Young Child Nutrition (WHO, 2014). WHO establishes several steps for completion that have been effective in substantially reducing overweight around the world, by providing interventions to improve diet and promote physical activity.

Intervention is a combination of elements or strategic programs designed to produce behavior change or improve health status among individuals or the entire population (Osuji, 2018). Shiman et al. (2018) showed that dietary interventions (including reducing intake of fast food and sugary drinks) for 2 years reduced BMI in overweight children (95\% $\mathrm{CI}=-0.14$ to o.06, $\mathrm{p}=0.040$ ).

Interventions for overweight children can be carried out in preschool (kindergarten or child care) and school. Children spend half of their waking hours and meals at school or daycare. Interventions include structured interventions delivered in school by teachers, or other professionals, that focus on physical activity, nutrition, and sedentary behavior. The duration of the intervention also affects the results of the study, the minimum time to stabilize changes involving practices such as physical activity and so on is 6 months (Henrique et al., 2016)

Interventions given at school to children provide evidence in reducing overweight with a reduced effect on BMI from 1 to $3 \mathrm{~kg} / \mathrm{m}^{2}$ (Bleich et al., 2017). Data from previous primary studies will be collected and analyzed using systematic reviews and meta-analyzes by synthesizing the results of studies conducted to reduce bias. This study aims to estimate the magnitude of the effect of school-based interventions on overweight in children based on a number of previous primary studies.

\section{SUBJECTS AND METHOD}

\section{Study Design}

This was a systematic review and meta-analysis. Research data were searched from a systematic and comprehensive electronic database of several indexing and hand searching. The databases used include: Google Scholar, PudMed, BMJ, ScienceDirect, BMC, and Sage. The keywords used include: (preschool OR school) AND (intervention OR program OR prevention) AND ("children obesity" OR "children overweight") AND "randomized control trials" and "preschool based" OR "school based" AND intervention OR prevention OR program AND "childhood obesity" OR "childhood overweight" OR "children obesity" OR "children overweight".

\section{Population and Sample}

Articles were searched considering the feasibility of using PICO. The study popu- 
lation was overweight children with intervention in the form of programs from preschool or elementary school, and the results of overweight children.

\section{Inclusion Criteria}

The inclusion criteria of this study used a Randomized Controlled Trial (RCT) study design with a Risk Ratio relationship measure. The research subjects were children who were overweight aged 4-12 years at the time when the intervention was started in the form of physical activity, nutrition or a combination thereof and the duration of the intervention was at least 6 months. The articles used are those from 2007 to 2018.

\section{Exclusion Criteria}

The exclusion criteria in this study were that the primary study was conducted with an observational design and the intervention was carried out not based on preschool or elementary school. The articles are those published in addition to English and Indonesian.

\section{Operational Definition of Variable} School-based interventions are strategic programs for managing and losing weight in schools. Instruments are in the form of a school-based physical activity program, nutrition or a combination there of with a categorical measuring scale.

Overweight is a medical condition that is described as being overweight in the form of fat characterized by a BMI of 2529.9. Instruments are in the form of a body scale and a stadiometer with a continuous measuring scale.

\section{Data Analysis}

Qualitative data analysis was carried out using previous research by Yin et al. (2014) and quantitative analysis was carried out using the Review Manager (RevMan) 5.3 program.

\section{RESULTS}

Research related to the effect of schoolbased interventions on overweight and obese children consisted of 10 articles from 3 continents, namely: Asia, North America, and Europe. 3 studies came from the Asian Continent (China), 3 studies from North America (Mexico and 2 from the United States), and 4 studies from the European Continent (Portugal, Germany, France, and England).

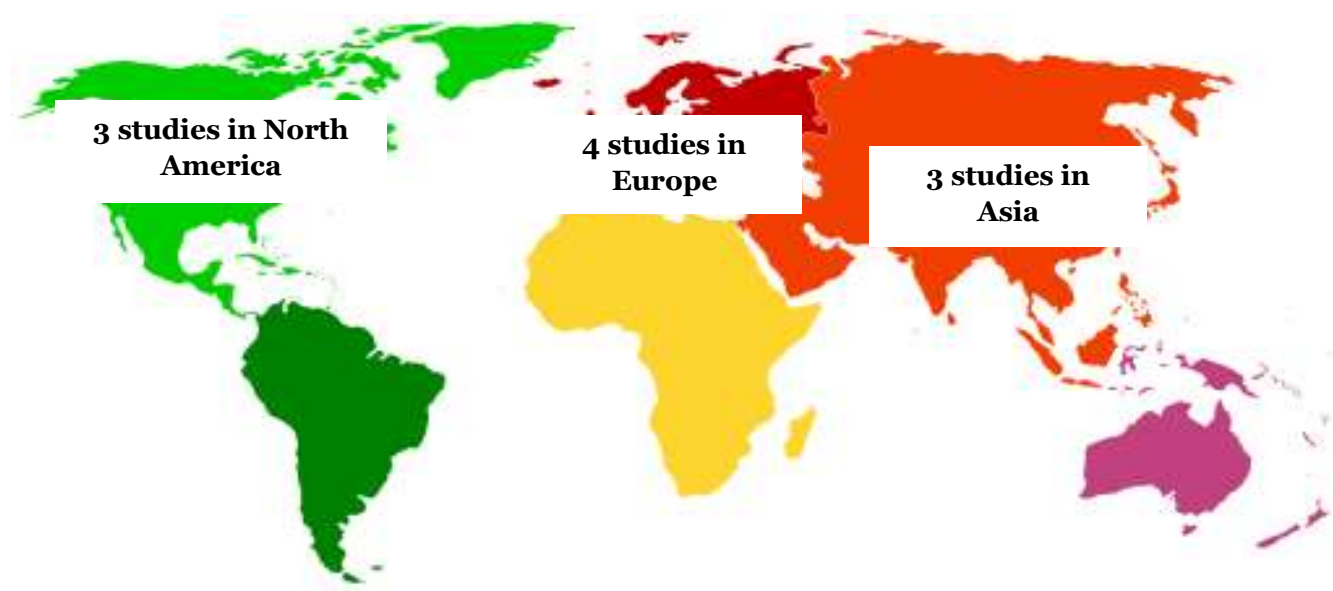

Figure 1. Map of the research area 
Nurlaili et al./ School Based Intervention on Overweight in Children

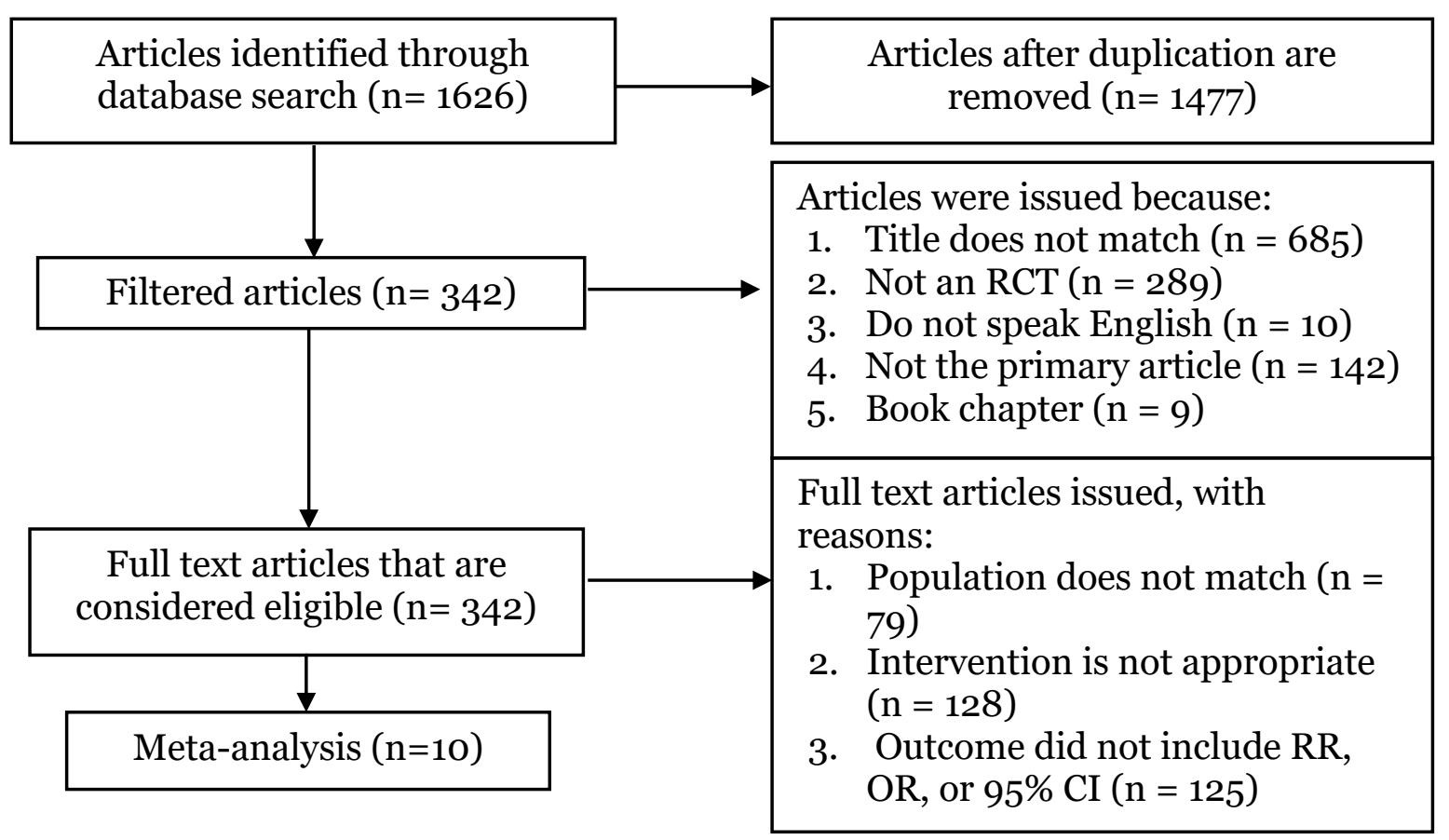

Figure 2. PRISMA flow diagram

We can see the interpretation of the results from the meta-analysis process through the forest plot and funnel plot. Figure 3 shows that school-based interventions can reduce the BMI of overweight children by 0.89 times compared to no intervention or only using the school curriculum in general and statistically significant $(\mathrm{RR}=0.89 ; 95 \% \mathrm{CI}=0.82$ to $0.97 ; \mathrm{p}=$ 0.007). The heterogeneity of the data shows $\mathrm{I}^{2}=0 \%$ so that the spread of data is declared homogeneous (fixed effect).

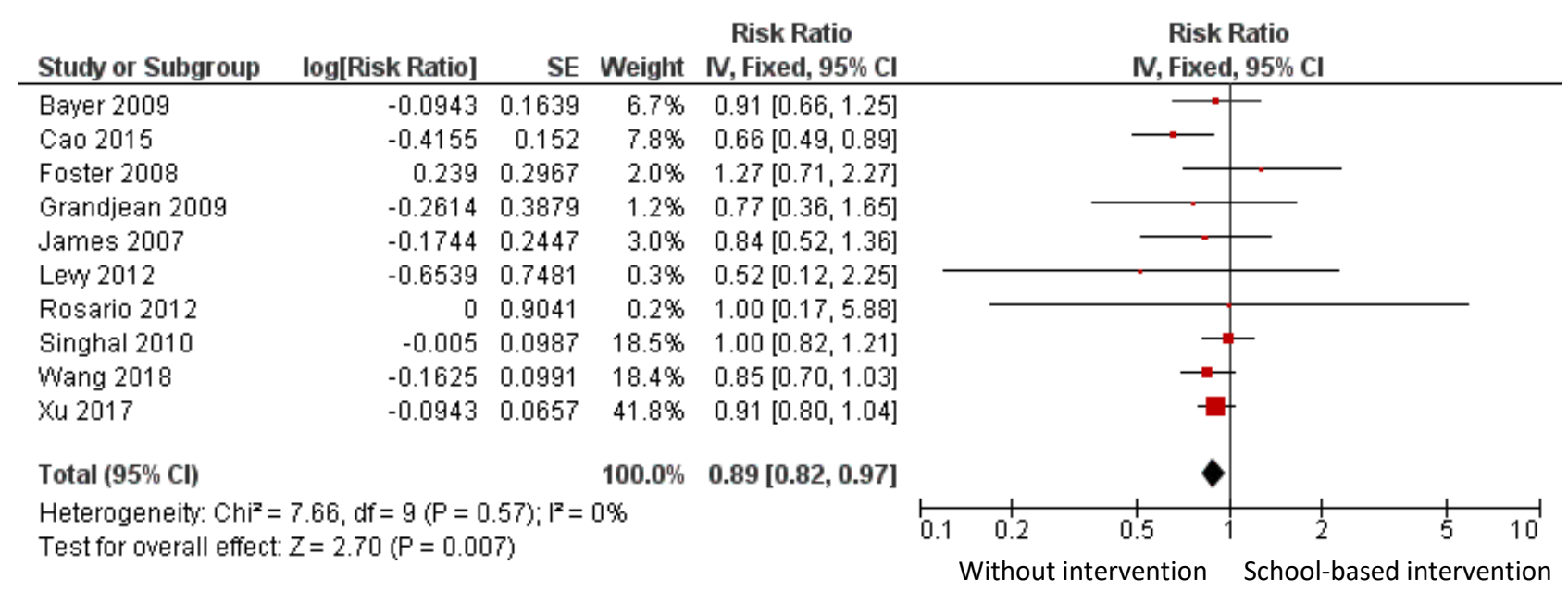

\section{Figure 3. Forest plot of influence of school based interventions on overweight in children}


Nurlaili et al./ School Based Intervention on Overweight in Children

Table 1. Critical appraisal of the effect of school-based interventions on overweight children

\begin{tabular}{|c|c|c|c|c|c|c|c|c|c|c|}
\hline Publication & Cohort & $\begin{array}{c}\text { With } \\
\text { Control }\end{array}$ & $\begin{array}{l}\text { Pre/ post } \\
\text { Interven } \\
\quad \text { tion }\end{array}$ & $\begin{array}{l}\text { Random } \\
\text { assign- } \\
\text { ment }\end{array}$ & $\begin{array}{c}\text { Random } \\
\text { selection of } \\
\text { assessments }\end{array}$ & $\begin{array}{c}\text { Sample } \\
>100\end{array}$ & $\begin{array}{c}\text { Follow } \\
\text { up } \\
\text { rate } \\
\geq \mathbf{8 0 \%}\end{array}$ & $\begin{array}{c}\text { Socio } \\
\text { demo- } \\
\text { graphics } \\
\text { between } \\
\text { studies }\end{array}$ & $\begin{array}{c}\text { Outcome } \\
\text { measures were } \\
\text { compared } \\
\text { between } \\
\text { studies }\end{array}$ & Total \\
\hline $\begin{array}{l}\text { Wang et al. } \\
\text { (2018) }\end{array}$ & 1 & 1 & 1 & 1 & 1 & 1 & 1 & 1 & 1 & 9 \\
\hline $\begin{array}{l}\text { Xu et al. } \\
(2017)\end{array}$ & 1 & 1 & 1 & 1 & 1 & 1 & 1 & 1 & 1 & 9 \\
\hline $\begin{array}{l}\mathrm{CaO} \\
(2015)\end{array}$ & 1 & 1 & 1 & 1 & 1 & 1 & o & 1 & 1 & 8 \\
\hline $\begin{array}{l}\text { Levy et al. } \\
\text { (2012) }\end{array}$ & 1 & 1 & 1 & 1 & 1 & 1 & 1 & 1 & 1 & 9 \\
\hline $\begin{array}{l}\text { Singhal } \\
(2010)\end{array}$ & 1 & 1 & 1 & 1 & 1 & 1 & 1 & 1 & 1 & 9 \\
\hline $\begin{array}{l}\text { Foster et al. } \\
\text { (2008) }\end{array}$ & 1 & 1 & 1 & 1 & 1 & 1 & o & 1 & 1 & 8 \\
\hline $\begin{array}{l}\text { Rosário et al. } \\
\text { (2012) }\end{array}$ & 1 & 1 & 1 & 1 & 1 & 1 & o & 1 & 1 & 8 \\
\hline $\begin{array}{l}\text { Bayer } \\
(2009)\end{array}$ & 1 & 1 & 1 & 1 & 1 & 1 & 1 & 1 & 1 & 9 \\
\hline $\begin{array}{l}\text { James } \\
(2007)\end{array}$ & 1 & 1 & 1 & 1 & 1 & 1 & 1 & 1 & 1 & 9 \\
\hline $\begin{array}{l}\text { Grandjean et } \\
\text { al. (2009) }\end{array}$ & 1 & 1 & 1 & 1 & 1 & 1 & o & 1 & 1 & 8 \\
\hline
\end{tabular}


Nurlaili et al./ School Based Intervention on Overweight in Children

Based on the assessment of the quality of the study using a rigor score for the RCT study design from previous studies, Yin et al. (2014), as many as 10 articles included in the quantitative syn- thesis meta-analysis were categorized as good articles. 10 articles were obtained about the effect of school-based interventions on overweight children.

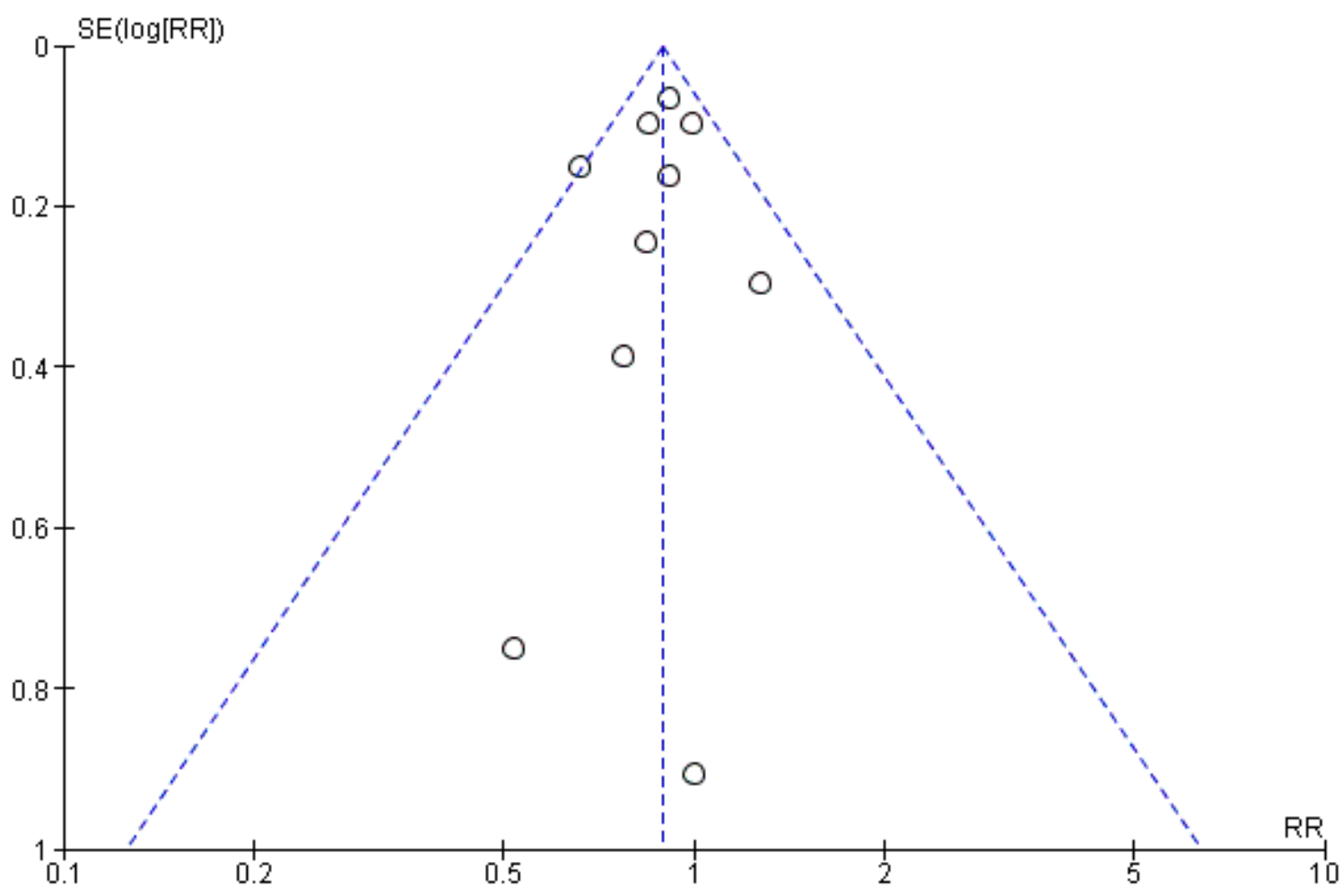

Figure 4. Funnel plot of the effect of school-based interventions on overweight children

Figure 4 shows a funnel plot where there is publication bias which is marked as not symmetrical in the right and left plots where there are 5 plots on the left and 3 plots on the right and 2 plots in the middle of the line. The plot on the left of the graph has a standard error between 0.8 and $\mathrm{o}$ and the plot on the right of the graph has a standard error between 1 and 0 has a standard error between 1 and o. Publication bias can be seen from the imbalance of distances between studies on both the right and left of the funnel plot. 
Table 2. Summary sources of the effect of school-based interventions on overweight children

\begin{tabular}{|c|c|c|c|c|c|c|c|c|}
\hline \multirow[b]{2}{*}{$\begin{array}{c}\text { Author } \\
\text { (year) }\end{array}$} & \multirow{2}{*}{ Country } & \multirow{2}{*}{$\begin{array}{l}\text { Number } \\
\text { of school }\end{array}$} & \multirow{2}{*}{$\begin{array}{l}\text { Total } \\
\text { sample }\end{array}$} & \multicolumn{2}{|c|}{$\begin{array}{l}\text { Number of pre samples; post (Mean; } \\
\text { age range) baseline }\end{array}$} & \multicolumn{2}{|c|}{ Type of Intervention } & \multirow{2}{*}{$\begin{array}{l}\text { Duration of } \\
\text { Intervention } \\
\text { (month) }\end{array}$} \\
\hline & & & & $\begin{array}{l}\text { Intervention } \\
\text { Group }\end{array}$ & Control Group & Intervention Group & Control Group & \\
\hline $\begin{array}{l}\text { Wang et } \\
\text { al. (2018) }\end{array}$ & China & 48 & 10091 & $\begin{array}{l}\text { Pra: 5400; post: } \\
5275(10.5)\end{array}$ & $\begin{array}{l}\text { Pra: 4691; post: } \\
4583 \text { (10.5) }\end{array}$ & $\begin{array}{l}\text { Physical activity, classroom } \\
\text { curriculum, support for the } \\
\text { school environment }\end{array}$ & $\begin{array}{l}\text { There is no } \\
\text { intervention }\end{array}$ & 12 \\
\hline $\begin{array}{l}\text { Xu et al. } \\
(2017)\end{array}$ & China & 38 & 7717 & $\begin{array}{l}\text { Pra: } 3536 ; \text { post: } \\
3476(9 ; 6-13)\end{array}$ & $\begin{array}{l}\text { Pra: 3541; post: } \\
3398(9 ; 6-13)\end{array}$ & $\begin{array}{l}\text { Nutrition and Physical } \\
\text { Activity }\end{array}$ & $\begin{array}{l}\text { There is no } \\
\text { intervention }\end{array}$ & 12 \\
\hline $\begin{array}{l}\text { Cao et al. } \\
(2015)\end{array}$ & China & 26 & 2446 & $\begin{array}{l}\text { Pra: } 1287 \text {; post: } \\
906^{\mathrm{f1}}, 573^{\mathrm{f} 2}, 271^{\mathrm{f}_{3}} \\
(8.9)\end{array}$ & $\begin{array}{l}\text { Pra: } 1159 \text {; post: } \\
800^{f_{1}}, 438^{f_{2}}, 107^{f_{3}} \\
(8.9)\end{array}$ & $\begin{array}{l}\text { Health education, diet, } \\
\text { physical activity, and family } \\
\text { support }\end{array}$ & $\begin{array}{l}\text { There is no } \\
\text { intervention }\end{array}$ & $\begin{array}{l}\mathrm{I}=12 \\
\mathrm{II}=36\end{array}$ \\
\hline $\begin{array}{l}\text { Levy et al. } \\
\text { (2012) }\end{array}$ & Mexico & 60 & 1019 & $\begin{array}{l}\text { Pra: } 510 ; \text { post: } \\
\text { 509 } 9^{\mathrm{f}}, 498^{\mathrm{f}},(9- \\
\text { 12) }\end{array}$ & $\begin{array}{l}\text { Pra: } 510 \text {; post: } \\
510^{f_{1}}, 499^{f_{2}},(9- \\
12)\end{array}$ & $\begin{array}{l}\text { Diet (breakfast of fruits and } \\
\text { vegetables) and physical } \\
\text { activity }\end{array}$ & $\begin{array}{l}\text { There is no } \\
\text { intervention }\end{array}$ & $\begin{aligned} \mathrm{I} & =6 \\
\mathrm{II} & =12\end{aligned}$ \\
\hline $\begin{array}{l}\text { Singhal } \\
(2010)\end{array}$ & $\begin{array}{l}\text { United } \\
\text { States of } \\
\text { America }\end{array}$ & 42 & 4610 & $\begin{array}{l}\text { Pra: 2311; post: } \\
2307 \text { (11.3) }\end{array}$ & $\begin{array}{l}\text { Pra: 2299; post: } \\
2296 \text { (11.3) }\end{array}$ & $\begin{array}{l}\text { Nutrition, physical activity, } \\
\text { behavioral knowledge, } \\
\text { skills, communication and } \\
\text { social marketing }\end{array}$ & $\begin{array}{l}\text { There is no } \\
\text { intervention }\end{array}$ & 24 \\
\hline $\begin{array}{l}\text { Foster et } \\
\text { al. (2008) }\end{array}$ & $\begin{array}{l}\text { United } \\
\text { States of } \\
\text { America }\end{array}$ & 10 & 1349 & $\begin{array}{l}\text { Pra: 6oo; post: } \\
479 \text { (11.2) }\end{array}$ & $\begin{array}{l}\text { Pra: 749; post: } \\
365(11.1)\end{array}$ & $\begin{array}{l}\text { Nutrition, physical activity, } \\
\text { behavioral knowledge and } \\
\text { skills }\end{array}$ & $\begin{array}{l}\text { There is no } \\
\text { intervention }\end{array}$ & 24 \\
\hline $\begin{array}{l}\text { Rosário et } \\
\text { al. (2012) }\end{array}$ & Portugal & 7 & 464 & $\begin{array}{l}\text { Pra: 233; post: } \\
151(8.3)\end{array}$ & $\begin{array}{l}\text { Pra: 231; post: } \\
143(8.2)\end{array}$ & Nutrition & $\begin{array}{l}\text { There is no } \\
\text { intervention }\end{array}$ & 6 \\
\hline $\begin{array}{l}\text { Bayer } \\
(2009)\end{array}$ & German & 64 & 1609 & $\begin{array}{l}\text { Pra: } 1049 ; \text { post: } \\
88^{\mathrm{f1}}, 866^{\mathrm{f} 2},(4-5)\end{array}$ & $\begin{array}{l}\text { Pra: } 560 ; \text { post: } \\
466^{\mathrm{f1}}, 463^{\mathrm{f} 2},(4-5)\end{array}$ & Diet and physical activity & $\begin{array}{l}\text { There is no } \\
\text { intervention }\end{array}$ & $\begin{aligned} \mathrm{I} & =6 \\
\mathrm{II} & =14\end{aligned}$ \\
\hline $\begin{array}{l}\text { Gran- } \\
\text { djean et } \\
\text { al. (2009) }\end{array}$ & France & 79 & 1325 & $\begin{array}{l}\text { Pra: 1030; post: } \\
697(5-6)\end{array}$ & $\begin{array}{l}\text { Pra: 1295; post: } \\
1290(5-6)\end{array}$ & $\begin{array}{l}\text { Nutrition education, } \\
\text { physical activity, and } \\
\text { sedentary behavior }\end{array}$ & $\begin{array}{l}\text { There is no } \\
\text { intervention }\end{array}$ & 24 \\
\hline $\begin{array}{l}\text { James } \\
(2007)\end{array}$ & English & 6 & 511 & $\begin{array}{l}\text { Pra: 219; post: } \\
219(7-11)\end{array}$ & $\begin{array}{l}\text { Pra: 202; post: } \\
215(7-11)\end{array}$ & $\begin{array}{l}\text { Diet (education and } \\
\text { reducing carbohydrates) }\end{array}$ & $\begin{array}{l}\text { There is no } \\
\text { intervention }\end{array}$ & 24 \\
\hline
\end{tabular}




\section{DISCUSSION}

This systematic review and meta-analysis research raises the theme of the effect of school-based interventions on overweight children. The independent variable is school-based intervention and the dependent variable analyzed is overweight children. The intervention was designed to reduce the BMI of overweight children in school with a randomized controlled trial design. Research that discusses overweight children is considered important because it is a problem in almost all countries, both developed and developing.

In this systematic review, 10 intervention studies were identified worldwide from 2007 to 2017. Each article had a study respondent $>400$ children. All articles obtained had statistical OR outcome. For reasons of data analysis, the researchers considered converting OR to RR. Calculating OR to RR is assisted by using https://clincalc.com/-stats/convertor.aspx.

Several previous studies such as that conducted by Suarez et al. (2009), Lavelle (2012), Yavuz (2015), and Wang et al. (2015), reported that the implementation of school-based interventions with a combination program of physical activity and nutrition had a positive effect. The primary studies that report the results of the intervention significantly provide a combined program of physical activity and nutrition. According to Bleich et al. (2017), a combination of physical activity and nutrition programs is more effective than a single program because of the wider scope and impact of the intervention. Program components in joint interventions vary widely in intensity of implementation. Choosing a school as the place for the intervention to be implemented is recognized as the ideal tool because children spend half of their waking hours and consume at least one third of their daily calories at school.
The results of the forest plot show that school-based interventions significantly reduce the BMI of overweight children by o.89 times compared to the group that was not given the intervention or that was only given the school curriculum in general significantly $(\mathrm{RR}=0.89 ; 95 \% \mathrm{CI}=0.82$ to 0.97; $\mathrm{p}=0.007$ ) . This meta-analysis study provides evidence to support school as an effective intervention in reducing the BMI of overweight children.

In this study, the changes seen were in the category of overweight, different from previous meta-analysis studies, where the study looked at changes in the mean BMI for classes consisting of underweight, normal, overweight, and obese. Previous meta-analyst research has not been able to answer the effectiveness of school-based interventions because they can cause outcome bias due to varying BMI values.

The results emphasize that schoolbased interventions in providing physical activity programs are very important. Physical activity programs are usually led by a physical education teacher and have a better structured schedule and intensity than those that include extracurricular activities only. The duration of the interventions given in this study ranged from 6 to 36 months. Based on research by Suarez et al. (2009), there was no difference in the long-term effectiveness of the intervention compared to controls in reducing the BMI of overweight children.

From this study, it can be concluded that school-based interventions significantly reduce the BMI of overweight children by o.89 times compared to the absence of intervention or school curriculum in general significantly $(\mathrm{RR}=0.89 ; 95 \% \mathrm{CI}=0.82$ to $0.97 ; p=0.007$ ). This meta-analysis of 10 RCT articles used a fixed effect models approach with $\mathrm{I}^{2}=0 \%$. 
Nurlaili et al./ School Based Intervention on Overweight in Children

\section{AUTHOR CONTRIBUTION}

Riftiani is the principal researcher who selects topics, explores and collects data. Yulia Lanti Retno Dewi and Rita Benya Adriani played a role in analyzing data and reviewing documents.

\section{CONFLICT OF INTEREST}

There is no conflict of interest in this study.

FUNDING AND SPONSORSHIP

This study is self-funded.

ACKNOWLEDGEMENT

We would like to thank database providers from Google Scholar, PubMed, BMJ, ScienceDirect, BMC, and Sage.

\section{REFERENCE}

Bleich SN, Vercammen, KA, Zatz, LY, Frelier, JM, Ebbeling, CB, Peeters A (2017). Review Interventions to prevent global childhood overweight and obesity: a systematic review. Lancet Diabetes Endocrinol. 8587(4): 1-15. https://doi.org/10.1016/s2213-8587(17)30358-3.

Cao ZJ, Wang SM, Chen Y (2015). A randomized trial of multiple interventions for childhood obesity in china. Am $\mathrm{J}$ Prev Med. 48(5): 552-56o. https://doi.org/10.1016/j.amepre.2014.12.014

Foster GD, Sherman S, Borradaile KE, Grundy KM, Vander VSS, Nachmani J, Shults J (2008). A policy-based school intervention to prevent overweight and obesity. Pediatrics, 121(4): 794-802. https://doi.org/10.1542/peds.2007-1365.

Grandjean H, Tauber M, Jouret B, Ahluwalia N, Dupuy M, Cristini C, Ne L (2009). Prevention of overweight in preschool children: results of kindergarten-based interventions. Int $\mathrm{J}$ Obes. 33(2009): 1075-1083. https://- doi.org/10.1038/ijo.2009.166.

Henrique P, Augusto J, Péricles E (2016). Physical activity and nutrition education at the school environment aimed at preventing childhood obesity: evidence from systematic reviews. J Pediatr (Rio J). 92(1): 15-23. https://doi.org/10.1038/ijo.2009.166.

James J, Thomas P, Kerr D (2007). Preventing childhood obesity: two year follow-up results from the christchurch obesity prevention programme in schools (chopps). BMJ. 335(7623): 762-764. https://doi.org/10.1136/bmj.39342.571806.55.

Kries V, Strauss A, Mitschek C, Toschke AM, Bayer O (2009). Short and midterm effects of a setting based prevention program to reduce obesity risk factors in children: a cluster-randomized trial. Am J Clin Nutr. 28(2): 122-128. https://doi.org/10.1016/j.clnu.2009.01.001.

Lavelle HV, Mackay DF (2012). Systematic review and meta-analysis of schoolbased interventions to reduce body mass index. J Public Health (Oxf). 34(3): 360-369. https://doi.org/10.1093/pubmed/fdr116.

Levy ST, Morales RC, Amaya CC, Salazar CA, Jiménez AA, Méndez G, Humarán I (2012). Effectiveness of a diet and physical activity promotion strategy on the prevention of obesity in Mexican school children. BMC Public Health. 12(152): 1-13. https://doi.org/10.1186/1471-2458-12-152.

Osuji CC (2018). Africa the Way Forward. UK: XlibrisUK.

Rosário R, Oliveira B, Araújo A, Lopes O, Padrão $\mathrm{P}$, Moreira A, Moreira $\mathrm{P}$ (2012). The impact of an intervention taught by trained teachers on childhood overweight. Int $\mathrm{J}$ Environ Res Public Health. 9(4): 1355-1367. https- 
Nurlaili et al./ School Based Intervention on Overweight in Children

://doi.org/10.339o/ijerph9041355.

Schwartz MW, Seeley RJ, Zeltser LM, Drewnowski A, Ravussin E, Redman LM, Leibel RL (2017). Obesity pathogenesis: An endocrine society scientific statement. Endocr Rev. 38(4): 130. https://doi.org/10.1210/er.201700111.

Shiman SL, Taveras EM, Gortmaker SL, Hohman KH, Horan CM, Kleinman KP, Gillman MW (2018). Two year follow-up of a primary care-based intervention to prevent and manage childhood obesity: the high five for kids study. Pediatr obes. 12(3): 1-6. https://doi.org/10.1111/ijpo.12141.

Simmonds M, Llewellyn A, Owen CG, Woolacott N (2016). Predicting adult obesity from childhood obesity: a systematic review and meta-analysis. Obes Rev. 17: 95-107. https://doi.org/10.1111/obr.12334.

Singhal, N Misra A (2010). A school-based intervention for diabetes risk reduction. N Engl J Med. 363(18): 17691770. https://doi.org/10.1056/nejmc1009969.

Suarez CG, Worley A, Grimmer-Somers K, Dones V (2009). School-based interventions on childhood obesity. Am J Prev Med. 37(5): 418-427. https://doi.org/10.1016/j.amepre.2009.07.01 2.

UNICEF, WHO, World bank (2020). Levels And Trends In Child Malnutrition. ISBN: 978-92-4-000357-6.

UNICEF (2016). Regional report on nutrition security in Asean vol 2. Jakarta: The ASEAN Secretariat.

Wang Y, Cai L, Wu Y, Wilson RF, Weston C, Fawole O, Cheskin LJ (2015). What childhood obesity prevention pro- grammes work? A systematic review and meta-analysis. Obes Rev. 16(7): 547-65. https://doi.org/10.1111/obr.12277.

Wang Z, Xu F, Ye Q, Tse LA, Xue H, Tan Z, Wang Y (2018). Childhood obesity prevention through a communitybased cluster randomized controlled physical activity intervention among schools in china: the health legacy project of the 2nd world summer youth olympic games (yog-obesity study). Int J Obes (Lond). 42(4): 625633. https://doi.org/10.1038/ijo.2017.243 .

WHO (2014). Comprehensive implementation plan for maternal, infant, and young child nutrition. Switzerland: WHO.

Xu H, Li Y, Zhang Q, Hu X, Liu A, Du S, Ma $G$ (2017). Comprehensive schoolbased intervention to control overweight and obesity in china: a cluster randomized controlled trial. Asia Pac J Clin Nutr. 26(6): 1139-1151. https://doi.org/10.6133/apjcn.112016.05.

Yavuz HM, Ijzendoorn MHV, Mesman J, Veek S, Van D (2015). Interventions aimed at reducing obesity in early childhood: a meta-analysis of programs that involve parents. J Child Psychol Psychiatry. 56(6): 677-692. https://doi.org/10.1111/jcpp.12330.

Yin L, Wang N, Vermund SH, Shepherd BE, Ruan Y, Shao Y, Qian HZ (2014). Sexual risk reduction for hiv-infected persons: a meta-analytic review of "positive prevention" randomized clinical trials. PLoS ONE. 9(9): 1-15. https://doi.org/10.1371/journal.pone. 0107652 . 